\title{
Belarusian Millennials: A Generation Gap?
}

\author{
ZHANNA GRISHCHENKO, LARISSA TITARENKO \\ Department of Sociology, Belarusian State University, 4 Niezaliežnasci Avenue, Minsk 220030, Belarus \\ Email:zhanna667@mail.ru; larisa166@mail.ru
}

\begin{abstract}
The authors focus on the generation of young Belarusian Millennials represented in this research by the students born in 1995-2000. Their main features include political indifference, everyday use of IT technologies, individualism and rational life attitudes. Taking into account both objective and subjective characteristics of this generation, the authors argue that it demonstrates a significant shift in societal development of Belarus. Under the social and cultural conditions of stability and political conservatism, the 'silent revolution' took place: Millennials transcoded the traditional values of the previous Soviet generations. The conceptualization of this phenomenon cannot be made only on the basis of quantitative data not capturing the new tendencies in youth development. The authors combine qualitative and quantitative methods that enhance a possibility to measure new meanings the youth puts into the basic values. This approach made it possible to discover the new youth features that may affect Belarusian development in the near future: its ambivalent self-identification, dominance of pragmatism and individualism. This phenomenon can be considered as a spontaneous reflection to the challenges that Belarus was facing during the post-Soviet transformation.
\end{abstract}

Keywords: Belarusian students, generation gap, Millennials, value shift, digital revolution, ambivalence

\section{INTRODUCTION}

In the last decades, the sociological global community was often discussing the new generations, Millennials and Z, as young cohorts radically changing the society. In particular, the concept of 'Millennials' as a generation born 15-20 years before the 2000 attracted attention of many authors (Strauss, Howe 1991). They stated that the new generation of youth is characterized by specific behavioural practices. A new attitude of the Millennials to the society was researched: Millennials seem to critically observe the social and political events and try to avoid participating in them. They live in their own virtual reality shared with other Millennials elsewhere.

Some authors pointed out that Millennials differ from the generations of Baby Boomers (1946-1961) and Generation X (1962-1981) because they are quickly adapting to the world undergoing rapid technological changes. Thus, Michelle Healy (2012), based on the research of a huge sample of American teenagers, contributed to the debates on Millennials denoting that they are more politically disengaged and more focused on materialistic values. According 
to this author, Millennials are more educated but less employed. American political scholars Michael Hais and Morley Winograd published two books on Millennials $(2008,2011)$. They interpreted this generation with the opposite characteristics: higher voting rates, increased volunteerism after high school and new types of jobs they wish (i.e. digitalized jobs). These researches empirically proved that Millennials represent significant cultural changes in the society in the era of digitalized revolution. Overall, the researchers constructed a concept of Millennials as a contradictory generation. They agreed that this generation differs from the previous ones in several aspects and highlighted their features.

Many American researches are focused on the political aspects of the attitudes and behaviour of this generation. For example, the Pew Research Center, that for decades has been committed to measuring public attitudes on key issues and documenting differences in those attitudes across demographic groups and generations, run several surveys on Millennials and discovered that this generation is much more advanced in technology, but still involved in voting process in the USA (Pew Research Center 2019). This Center also stated that the post-millennial generation (the so-called Generation Z) can be counted from the very end of the 20th century. However, the boundaries between the generations are discussed: some other authors continue to argue that Generation $\mathrm{Z}$ has started its existence from 2001.

Beyond the USA the topic of generation shift is also under research. Thus, L. Kardeliene mentioned (2011) that in Lithuania this generation of students demonstrate a lifestyle that can be described as existential escapism. In Russia the most known author on Millennials, V. Radaev, recently published a book on this topic (2019). He defined Millennials as being born between 1982 and 2000 and pointed out a radical value gap between them and the previous generation. As Radaev found out, Russian Millennials are better educated and broadly use digital tools in their activities, however, they later join the labour market and start their own family. Overall, the analysis of literature presents that some features of Millennials selected by different authors are similar, although some other features may differ depending on a particular country.

Regardless of the existing numerous publications on this generation, there was no research referred to Belarusian Millennials. Being a post-Soviet country, Belarus differs in some important social and political aspects from Russia and other neighbouring countries, not even mentioning the advanced western countries. The aim of the present article is to address the concept of Belarusian Millennials based on the empirical research. Our object of research is a cohort of Belarusian students born in 1995-2000. We want to reveal the features of this cohort that represents Belarusian Millennials. Our goal is to show that this generation demonstrates a latent social gap in the societal development of Belarus under the visible social stability and economic sustainability.

Our research was made in 2016-2019. We combined several methods (from quantitative surveys to qualitative narrative interviews, essays and focus groups) pointing out the difficulties in the measurement of mental changes of Belarusian students. A set of selected methods helped to discover the new meanings respondents attributed to the concepts broadly used in the surveys. According to the social background of our respondents we may conclude that they represent not only ten universities being researched in Minsk but the whole students' cohort as our respondents were born in different regions of Belarus. However, as our surveys were relatively small (from 425 to 500 respondents), and the object of our study (a cohort of Belarusian students) represented only a part of the Millennials, we consider our conceptualization of Belarusian Millennials as an initial step in this direction that requires confirmation in further investigation. 


\section{RESULTS AND DISCUSSION}

For the beginning, we checked the data collected by other scholars and referred to Belarusian Millennials. Quite often the discussion on the post-Soviet value transformation of youth in Belarus was based on the evolutionary approach developed by American political scientist Ron Inglehart, a former director of the World Values Survey. According to this approach (Inglehart 1997, 2018), a significant cultural change in post-Soviet countries (like elsewhere in the world) demonstrates that the traditional domination of family, work, politics and religion is steadily substituted by the post-traditional (post-materialistic) model of thought and practice with the dominance of individual autonomy, democracy, gender equality, leisure time and self-realization. This theory was empirically proved in several surveys within the framework of the World Values/European Values Study in more than hundred countries. Because Belarus was a part of these surveys, it was possible to make our analysis. In order to have a sample of Millennials, we took data from the last national survey run in Belarus in 2017 within the framework of the last EVS wave (European... 2019). From the national sample (1,000 persons) we selected those who were born in 1982-1999 - Belarusian Millennials belonging to different social groups. The sample included 302 persons of this age group.

For our research purpose the very first question from the EVS questionnaire was taken for the analysis. It contained a list of the so-called 'core values' (work, family, leisure time, friends, politics, religion) that respondents had to assess using a scale from 'not at all important' to 'very important.' This question only listed the values and did not provide any interpretation of the meanings of each of them. Each respondent could follow his/her own interpretation. This situation made the whole question rather formal. The formal analysis of the 2017 data made by Belarusian scholars confirmed that Belarusian population is rather traditional as traditional values still prevail among the people (Artsiomenka 2019).

Our analysis of the sample of Belarusian Millennials also proved that family was their most important life value (around $88 \%$ of respondents expressed this opinion), while values of work and friendship went the second and the third. It is interesting to mention that similar youth cohorts in the neighbouring Russia, Ukraine, Poland and Lithuania demonstrated the same priorities. It is quite possible that such results cannot disclose the real situation: probably, the answers repeated the traditional stereotypes about the importance of family in our society, although some authors insist that family is an unconditional value for the most Belarusians (Bubnov 2007). We consider these results as an example how a quantitative questionnaire can level out the opinions and behaviour of different generations and cannot help in capturing the new trends that are already taking place in a society - at least in regard to the younger generation.

However, even within the EVS study some post-traditional attitudes were discovered: first, it was a priority of the gender equality principle in the distribution of homework between the partners (Artsiomenka 2019). This change indicates a new tendency within a family - a shift to the post-materialist way of life - that is not clearly visible for all generations but already articulated by the Millennials. Also, less part of the young respondents in 2017 than in the previous EVS surveys agreed that 'a woman wants to stay at home with a child' and therefore does not want to have a job (from 18\% in 2000 to 15\% in 2017). Additionally, only $16 \%$ of the respondents agreed that 'to have a child is an everybody's duty'. Overall, the familist values, a bastion of traditional society (Antonov, Sorokin 2000), seem to be not the same for the Millennials. 
The tendency toward more gender equality in Russia was found out as well (Vannoy et al. 1999), so that we consider it as a common trend. However, Russian feminists have to constantly fight with their traditional opponents (Temkina, Zdravomyslova 2014). In Belarus such debates in the public do not exist.

In our own surveys where we focused only on the cohort of the students born in 19952000, the results revealed a new understanding of work supported by the Millennials. Some issues were identified that distinguish the generation of Millennials from the obsolete type of the Soviet personality. Firstly, the most popular motivation for study at the university expressed by the students included two statements: 'desire to have a stable well-being in the future' and 'desire to be a qualified specialist' (each supported by $22 \%$ respondents). Also, one in seven students said that 'diploma on higher education is always a plus in the future'. Nobody expressed the motives associated with the recognition of the social significance of their profession or the desire to contribute to the society - typical statements for the so-called 'Soviet simple person', i.e. a model researched in different variations by Yuri Levada and his colleagues in the Soviet and early post-Soviet periods (Levada 1993). Recently Levada's collaborator Lev Gudkov in his interview to Belarusian non-government media mentioned that initially Levada's hypothesis assumed that the Soviet type of personality would disappear together with the Soviet Union. However, as Gudkov explained, in the 21st century the researchers discovered that 'Soviet man reproduces himself... Sovietism is in the heads of people, despite the fact that the USSR is no longer there' (Gudkov 2017). We cannot discuss whether this type of personality indeed still exists in Russia. However, we assume on the basis of our research data that the generation of Belarusian Millennials has nothing in common with this type. Their post-Soviet socialization was determined by the new reality more influenced by the Internet than by the Soviet past.

Secondly, the difference between the Soviet type of personality and Belarusian Millennials refers to the criteria of selecting their future workplace. Despite the official propaganda that graduates have to accept any workplace the state authorities provide for them, our respondents want only a job that satisfies their personal needs. The respondents clearly indicated that the major characteristics of a future job they wish are the following: good work conditions, good opportunities for a career and good payment. All above-mentioned criteria were more or less equally important for the students who viewed their professional self-realization through the prism of personal well-being. These criteria were assessed as the highest. Future job was considered as the means for achieving a high level of well-being and not as a core value in their life. At the same time the students expressed their desire to have an interesting job that will help to develop their personality. More than $25 \%$ of the students in our survey stated that a new generation would be very innovative at their workplace (Titarenko 2016). Probably, when expressing their innovative ability, the students mainly relied on their high level of digitalization. This feature distinguishes the Millennials from the previous generations most of all and provides them a chance to demonstrate a higher level of IT competences that are always in need in the Belarusian society badly seeking for digital modernization.

Such ambivalence in the students' views (combination of pragmatism and desire for self-realization at workplace) can be interpreted as the inner contradiction of the Millennials' personality that reflects the duality of the whole Belarusian society. On the one (external) hand, Belarusians seem to be tolerant and undemanding, on the other (internal), they are pessimistic, unsatisfied, trying to change their life but often feeling unable to do that. 
The students are not yet totally pessimistic about Belarusian reality, but they are skeptical about their life chances in Belarus and do not consider themselves obliged to continue such life.

It is worth mentioning the results received by the qualitative methods (narrative interview and essay) as they provided a possibility to capture the latent characteristics of the Millennials. We assume that these methods have a higher cognitive potential when dealing with the inner world of young people and essentially help in a deeper understanding of this generation. The students were asked to freely express their ideas about a number of political issues and determine how they view themselves.

Using qualitative methods during the study along with quantitative surveys made it possible to fix the imbalance between the national and civic identifications of students. If the first gravitates toward positive assessments, the second turns toward the negative ones. For example, their perception of the statement 'I am Belarus and proud of it' received a high verbal approval (more than two thirds of the students). At the same time, the slogan constantly broadcast by the Belarusian television - 'Belarus is a country for life' - was rejected by $70 \%$. We believe that a negative attitude to this slogan is based on the emotional assessment of its meaning not supported by personal everyday practices. The content-analysis of the narrative interviews (74 were received in 2018) contributed to the understanding the meanings of positive attitudes of Belarusian Millennials toward a desirable model of self-realization abroad and their negative attitudes in regard to the imposed national image of lifestyle.

Millennials' attitude to the political field is not as clear as it may seem. At the empirical level, the indifference of the vast majority of Belarusian students to various forms of political activity is fixed. This feature of Belarusians was indicated by the Nobel winner Svetlana Alexievich: according to her views, based on her observations, Belarusian society is constantly reproducing a type of 'Red personality', and young Millennials do not radically differ from the generation of their Soviet parents. We do not fully agree with Alexievich in regard to the young students. They are negative to politics, but participate in the voluntary forms of social activities that allow them to express innovations and creativity: defending animals, helping the low-income families, supporting the ecology, and the like. The traditional political field does not leave a space for free self-realization. Millennials are convinced that in the modern political practice the struggle for power has become an end in itself for both sides.

The official Belarusian ideology states that young generation is patriotic. Meanwhile Millennials view patriotism not in the same way as the ideologists assume. Belarusian students are free from ideological attitudes of the past and place bets on new mechanisms for the implementation of a successful life project. According to the narrative interviews, the new popular social technology of self-realization for a modern student is the prospect of 'going abroad to earning or continuing studies'. The scholars have to admit the presence of this obvious tendency, albeit it is unpleasant for the official propaganda. Over the past two decades a desire to go abroad has been growing among the students, together with growth of the possibilities to do that (tourism, trainings, etc.). The Bologna process has expanded the possibilities for students to travel abroad officially. Therefore, more than three quarters of our respondents indicated their readiness to go abroad, however, 'subject to suitable conditions'.

Shall we conclude that these students are not patriotic? They live in a virtual reality and perfectly know that western countries are technically advanced and have a higher standard of living than Belarus. Western societies seem to be attractive for them: young people want to see this life with their own eyes and try to find a space for themselves there. First of all, 
the desire to go abroad is a matter of their pragmatic interest in expanding the possibilities of implementing a successful life project. To some extent, this pragmatic interest is backed by the high IT-competencies of Millennials that they received during their study at the universities. To a greater extent, pragmatism of the Belarusian Millennials was formed under the influence of widespread dehumanization of higher education sphere (a sharp reduction in the programs of social and cultural studies, humanities if these disciplines are not related to the narrow professional knowledge) and commercialization, which led to a decrease in the quality of education at a university and a decline in its prestige in society. Young people do not appreciate a diploma and do not consider it as social capital if it can be acquired on a paid basis as any market goods. We assume that it is unlikely that the Belarusian system of higher education reinforces patriotism in the sense that was inherited from our pre-Soviet ancestors: 'Life to the Motherland, and honor to anyone'. All the above-mentioned factors contributed to the process of socialization of the young generation as pragmatic, rational and individualistic. So, there is not a surprise that youth can view themselves as patriotic and dream to leave a country at the same time if it helps to get a life success.

A similar ambivalence was shown by young Millennials on the so-called 'language issue', which for a long time served as a field of national debate between the ruling elite and different segments of the nationalist opposition. According to our results, the students critically assess these debates. ${ }^{1}$ The youth attitude to the national debates on Belarusian as the only language of communication is dual. On the level of rhetoric, the students express their respect for Belarusian. However, in $90 \%$ of essays they said that 'language area' of discussions is highly politicized and therefore not attractive for them. Millennials are rational in their attitudes and care about their own practical interests. Thinking about a chance to go abroad they understand that learning English is more practical than learning Belarusian. Most students do not agree to shift to Belarusian in their everyday life. Their respect for Belarusian is more verbal; while English courses are practically popular because foreign languages can help in their life strategy to study abroad or find a job there.

At the same time, $26 \%$ of the students would like to choose power as their preferred social technology for achieving life success. It is possible that in the near future the power institutions in Belarus will be replenished with human resources that openly express their goals to use the power resource as a career tool for approaching various types of capital - economic, cultural, symbolic - which this generation would like to get for personal pragmatic interests. Given that Millennials will soon become the dominant reserve of personnel policy, social scholars can anticipate some possible negative consequences of their inclusion in the Belarusian power elites. They can hardly contribute to the development of an already weak civil society in Belarus.

The modern generation of students do not veil its main stake on the self-assertion of the sovereign autonomy in the form of individualism, focused on achieving personal life success. The mainstream of the 'mental paths' of students forming before our eyes is aimed at affirming a person understood as 'the ability to remain oneself' under any social conditions. Hence it is clear why the model of autonomy and individual freedom adopted by the Millennials does not allow them to accept any role models and excludes the dominant role of any authorities for this generation. These models are viewed as a threat to the youth autonomy and self-identity.

1 Their views on the nationalist actions are in line with the position expressed by the US scholar Per Rudling (2014) who deconstructed the context of nationalist activities in Belarus. 


\section{CONCLUSIONS}

The authors demonstrate in this article that the phenomenon of Belarusian Millennials is essential for the analysis of social trends in the country's development. This generation is not yet a significant social force in a society, but it already changes the image of Belarusians. The students identify themselves as patriots while are ready to emigrate 'under the proper conditions.' They express verbal respect to the native language while speak Russian and prefer to learn foreign languages as 'it is more practical'. They are skeptical in regard to the official politics but ready to use the power resources for their own career.

The authors conclude that subjective meanings attributed by the Belarusian students to the core values made these concepts individualistic and post-modern rather than traditional. Young Millennials focus on their own career and well-being, search for well-paid job regardless of the profession; they seriously study only those disciplines that they consider 'necessary' for their career. They highly evaluate family but prefer personal relations without moral duties and responsibilities.

The authors reason out that the measurement of subjective meanings of youth values is essential in the research. This approach allows us to view the current cohort of Belarusian students as similar to the Millennials in other countries in such things like self-image, life style, criticism and life prospects. Belarusian Millennials have nothing in common with the Soviet past and do not want to continue traditions of their parents. Comparing their own position with referent groups abroad they will not model their parents or 'heroes' that mass media impose on them.

Received 16 October 2019

Accepted 15 November 2019

\section{References}

1. Antonov, A. I.; Sorokin, S. A. 2000. The Fate of the Family in Russia in the 21st Century. Reflections on Family Policy, on the Possibility Counteracting Family Decline and Depopulation. Moskva: Graal' (in Russian).

2. Artsiomenka, A. 2019. 'Family Values of Belarusians as a Pillar of Sustainable Development of the State', SOTIS: Social Technologies, Research 2: 89-98 (in Russian).

3. Bubnov, Yu. M. 2007. Sociological Overview of Gender Relations. Minsk (in Russian).

4. European Values Study. General Information about the European Values Study. Available at: https:// www.europeanvaluesstudy.eu/ (accessed 14.03.2019).

5. Healy, M. 2012. 'Millennials Might Not Be So Special After All, Study Finds', USA Today 3/15/2012. Available at: https://usatoday30.usatoday.com/news/health/wellness/story/2012-03-15/Millennialsmight-not-be-so-special-after-all-study-finds/53552744/1 (accessed 26.06.2019).

6. Inglehart, R. 1997. Modernization and Postmodernization: Cultural, Economic, and Political Change in 43 Societies. Princeton: Princeton University Press.

7. Inglehart, R. 2018. Cultural Evolution. How People's Motivations are Changing and How This is Changing the World. Moskva: Mysl' (in Russian).

8. Lev Gudkov on the Survivability of Soviet Man. 2017. An Interview, posted in The EHU Times on 24 June 2017. Available at: https://ehutimes.com/2017/06/24/ \%BE-\%D1\%87\%D0\%B5\% D0\% BB/ (accessed 25.05.2018).

9. Levada, Yu. (ed.). 1993. Soviet Simple Person: Experience of a Social Portrait on the Edge of the 1990s. Moskva: Mirovoy Okean (in Russian).

10. Pew Research Center. 2019. Millennials. Available at: https://www.pewresearch.org/topics/Millennials/ (accessed 05.10.2019).

11. Radaev, V. V. 2018. 'Millennials on the Background of Previous Generations: An Empirical Analysis', SOCIS 3: 15-33 (in Russian).

12. Radaev, V. V. 2019. Millennials. How Russian Society is Changing. Moscow: Higher School of Economics (in Russian). 
13. Rimashevskaya, M. N. 1992. Women in a Changing World. Moscow: Nauka (in Russian).

14. Rudling, P. A. 2014. The Rise and Fall of Belarusian Nationalism. Pittsburgh: University of Pittsburgh Press.

15. Strauss, W.; Howe, N. 1991. Generations. New York.: William Morrow \& Co.

16. Tartakovskaya, I. N. 2005. Sociology of Gender. Moscow: Variant (in Russian).

17. Temkina, A.; Zdravomyslova, E. 2014. 'Gender's Crooked Path: Feminism Confronts Russian Patriarchy', Current Sociology 62(2): 253-270.

18. Titarenko, L. G. 2016. 'Modernization Values of Students as a Resource for Innovative Development of Belarus', Philosophy and Social Sciences 3: 70-74 (in Russian).

19. Vannoy, D.; Rimashevskaya, N.; Cubbins, L.; Malysheva, M.; Meshterkina, E.; Pisklakova, M. 1999. Marriages in Russia. Couples During the Economic Transition. Westport, CT: Praeger.

20. Winograd, M.; Hais, M. D. 2011. Millennial Momentum: How a New Generation is Remaking America. New Brunswick: Rutgers University Press.

21. Winograd, M.; Hais, M. D. 2008. Millennial Makeover: MySpace, YouTube and the Future of American Politics. New Brunswick: Rutgers University Press.

\title{
ŽANA GRIŠČENKO, LARISA TITARENKO
}

\section{Tūkstantmečio karta Baltarusijoje: kartų atotrūkis}

\begin{abstract}
Santrauka
Koncentuojamas dèmesys ị tūkstantmečio (angl. millennials) kartą Baltarusijoje - tiriama 1995-2000 m. gimusių studentų elgsena. Pagrindiniai šios kartos bruožai - politinis abejingumas, kasdienis IT (informacinių technologijų) naudojimas, individualizmas ir racionalizmas. Autorès remiasi tiek objektyviomis, tiek subjektyviomis šios kartos charakteristikomis ir tvirtina, kad tyrimo duomenys rodo esmini Baltarusijos socialinès raidos kartų atotrūkį. Socialinio-kultūrinio stabilumo ir politinio konservatyvumo sąlygomis ịvyko „tylioji revoliucija“: tūkstantmečio karta atitrūko nuo ankstesnių sovietinių kartų, buvusių vertybių. Šio reiškinio konceptualizavimui nepakanka vien kiekybinio tyrimo, nes jis nefiksuoja naujų jaunimo mąstymo ir elgesio raidos tendencijų. Tyrime naudojami kokybiniai ir kiekybiniai metodai, didinantys galimybes matuoti naujas reikšmes, kurias jaunimas suteikia ịprastoms vertybėms. Šie metodai sudaro galimybes atskleisti naujus jaunimo bruožus, kurie gali turèti ịtakos Baltarusijos, kaip valstybès, ateičiai: jaunimo ambivalentiškumas, pragmatizmas ir individualizmas. Šis fenomenas gali būti traktuojamas kaip spontaniška refleksija i iššǔkius, kurie iškilo Baltarusijoje posovietiniu laikotarpiu.
\end{abstract}

Raktažodžiai: Baltarusijos studentai, tūkstantmečio karta, kartų atotrūkis, vertybinis posūkis, skaitmeninè (digitalinè) revoliucija, ambivalentiškumas 